\title{
Why does the world need another rotavirus vaccine?
}

\author{
Richard L Ward' \\ Monica M McNeal' \\ A Duncan Steele ${ }^{2}$ \\ 'Division of Infectious Diseases, \\ Cincinnati Children's Hospital \\ Medical Center, Cincinnati, $\mathrm{OH}$, \\ USA; ${ }^{2}$ Initiative for Vaccine Research, \\ World Health Organization, Geneva, \\ Switzerland
}

\begin{abstract}
A "Meeting on Upstream Rotavirus Vaccines and Emerging Vaccine Producers" was held at the World Health Organization in Geneva, Switzerland on March 28-30, 2006. The purpose was to discuss, evaluate, and weigh the importance of additional rotavirus vaccine candidates following the successful international licensure of rotavirus vaccines by two major pharmaceutical companies (GlaxoSmithKline and Merck) that had been in development for many years. Both licensed vaccines are composed of live rotaviruses that are delivered orally as have been all candidate rotavirus vaccines evaluated in humans. Each is built on the experience gained with previous candidates whose development had either been discontinued or, in the case of the previously licensed rhesus rotavirus reassortant vaccine (Rotashield), was withdrawn by its manufacturer after the discovery of a rare association with intussusception. Although which alternative candidate vaccines should be supported for development and where this should be done are controversial topics, there was general agreement expressed at the Geneva meeting that further development of alternative candidates is a high priority. This development will help insure that the most safe, effective and economic vaccines are available to children in Third World nations where the vast majority of the $>600,000$ deaths due to rotavirus occur each year. This review is intended to provide the history and present status of rotavirus vaccines as well as a perspective on the future development of candidate vaccines as a means of promulgating plans suggested at the Geneva meeting.
\end{abstract}

Keywords: rotavirus vaccines, rotavirus immunity, candidate vaccines

\section{Introduction}

In January, 2006, reports on the safety and efficacy of two rotavirus vaccine candidates, that had recently been or were about to be licensed in several countries, were published back-to-back in The New England Journal of Medicine (Ruiz-Palacios et al 2006; Vesikari et al 2006). These reports represented the combined efforts of many hundreds of investigators, the cooperation of many thousands of study subjects and their parents, and the expenditure of several billion dollars by funding agencies and pharmaceutical companies. They also represented at least a temporary crest in the roller coaster ride that led to their development. The question now is, will this ride continue upward with these candidate vaccines and, if so, should it be joined by alternative rotavirus vaccine candidates. One purpose of this review is to list notable events that occurred over the past 60 years which have contributed to the successful licensure of these two vaccines. The second purpose is to describe the most viable alternative rotavirus vaccine candidates with particular emphasis on answering the question of why they are needed.

\section{Discovery of rotavirus and its associated disease}

The first rotaviruses to be described, based on pathology and epidemiology, were murine strains which were classified under the general description as the agents 
responsible for "epizootic diarrhea of infant mice" ie, EDIM (Cheever and Mueller 1947; Pappenheimer and Enders 1947). Murine rotaviruses were also among the first to be visualized by electron microscopy (Adams and Kraft 1963). Viruses with comparable morphologic features were observed in that same year in rectal swab specimens of monkeys (Malherbe and Harwin 1963). These agents were described as 70-nm particles that had a wheel-like appearance and, hence, were later designated "rota" viruses from the Latin word for wheel (Flewett et al 1974; Wyatt et al 1978). In 1969, Mebus et al (1969) demonstrated the presence of these particles in stools of calves with diarrhea, thus associating these viruses with a diarrheal disease in cattle. The correlation between these viruses and severe diarrhea in young children was reported first in 1973 by Bishop et al (1973) who used electron microscopy to examine biopsy specimens of duodenal mucosa from children with acute gastroenteritis. Within a short time, these and other investigators confirmed the association between the presence of rotavirus in feces and acute gastroenteritis.

In addition to their distinctive morphologic features, human rotaviruses along with their animal counterparts were shown to share a group antigen (Kapikian et al 1976; Woode et al 1976) and were classified as members of the Rotavirus genus within the Reoviridae family (Matthews 1979). In 1980, particles that were indistinguishable morphologically from established rotavirus strains but lacked the common group antigen were discovered in pigs (Bridger 1980; Saif et al 1980). This finding subsequently led to the identification of rotaviruses belonging to six additional groups (B to $G$ ) based on common group antigens, with the original rotavirus strains classified as group A (Saif and Jiang 1994). Only groups A to C have been associated with human diseases, and most known cases of rotavirus gastroenteritis have been caused by group A strains.

Today, rotaviruses are recognized as the primary cause of severe infantile gastroenteritis worldwide (de Zoysa and Feachem 1985). In the United States, as in other developed countries, these viruses are responsible for numerous hospitalizations in young children but are estimated to cause relatively few deaths (Glass et al 1991, 2006). On a world scale, however, rotaviruses are believed to be the cause of $>600,000$ deaths each year (Glass et al 2006; Parashar et al 2006). For these reasons, rotaviruses have received a high priority as a target for vaccine development (Institute of Medicine 1986; Research priorities for diarrheal diseases vaccines 1991; GAVI 2001).

\section{What is rotavirus?}

A computer-generated image of the rotavirus particle obtained by cryoelectron microscopy (Figure 1) showed that it is approximately $100 \mathrm{~nm}$ in diameter and has a capsid composed of three concentric protein layers (Shaw et al 1993; Prasad and Chiu 1994). The outer layer contains the VP7 glycoprotein (780 molecules/virion) and 60 dimers or trimers of the VP4 protein (Yoder and Dormitzer 2006), the latter of which forms spikelike projections that extend through and 11-12 nm beyond the VP7 layer (Prasad and Chiu 1994; Shaw et al 1993; Yeager et al 1994). Cleavage of the VP4 protein prior to cell attachment by trypsin-like enzymes into two peptide fragments (VP5* and VP8*) that remain associated with the virus particle enhances its infectivity. The VP4 protein is anchored to the intermediate layer of the particle composed of 780 molecules of the VP6 protein. The innermost layer contains 120 molecules of the VP2 protein that interact with 12 molecules each of the viral transcriptase (VP1) and guanylyltransferase (VP3) along with the 11 segments of double-stranded RNA genome. These segments encode the 6 structural proteins of the virus as well as 6 non-structural proteins designated NSP1-NSP6 (Table 1). The smallest segment encodes both NSP5 and NSP6. The genome segments range in size from ca. 660 to 3300 base pairs; their encoded proteins, the functions of which are at least partially understood, have molecular weights of ca. 12,000 to 125,000 .

The genome segments of rotavirus can be extracted from viral particles and separated by polyacrylamide gel electrophoresis into 11 distinct bands visualized by ethidium bromide or silver staining (Figure 2). Each rotavirus strain has a characteristic RNA profile or electropherotype, a property that has been used extensively in epidemiologic studies of these viruses. The characteristic RNA electrophoretic pattern of group A rotaviruses consists of four size classes containing segments $1-4,5$ and 6,7-9, and 10 and 11. RNA segments of strains belonging to less well characterized rotavirus groups (ie, groups B to G) also can be separated into size classes, but the distribution of segments within these classes differs from group to group.

\section{Serotypes of rotavirus}

Both outer capsid proteins of rotavirus, VP4 and VP7, contain neutralization epitopes and, thereby, both are involved in serotype determination, an important consideration in vaccine development. Originally, serotyping was based solely on differences in the VP7 protein because when animals were hyperimmunized with rotaviruses they developed almost all neutralizing antibody to this protein and cross-neutralization studies conducted with these hyperimmune sera readily separated the strains into VP7 serotypes (Hoshino et al 1984; 


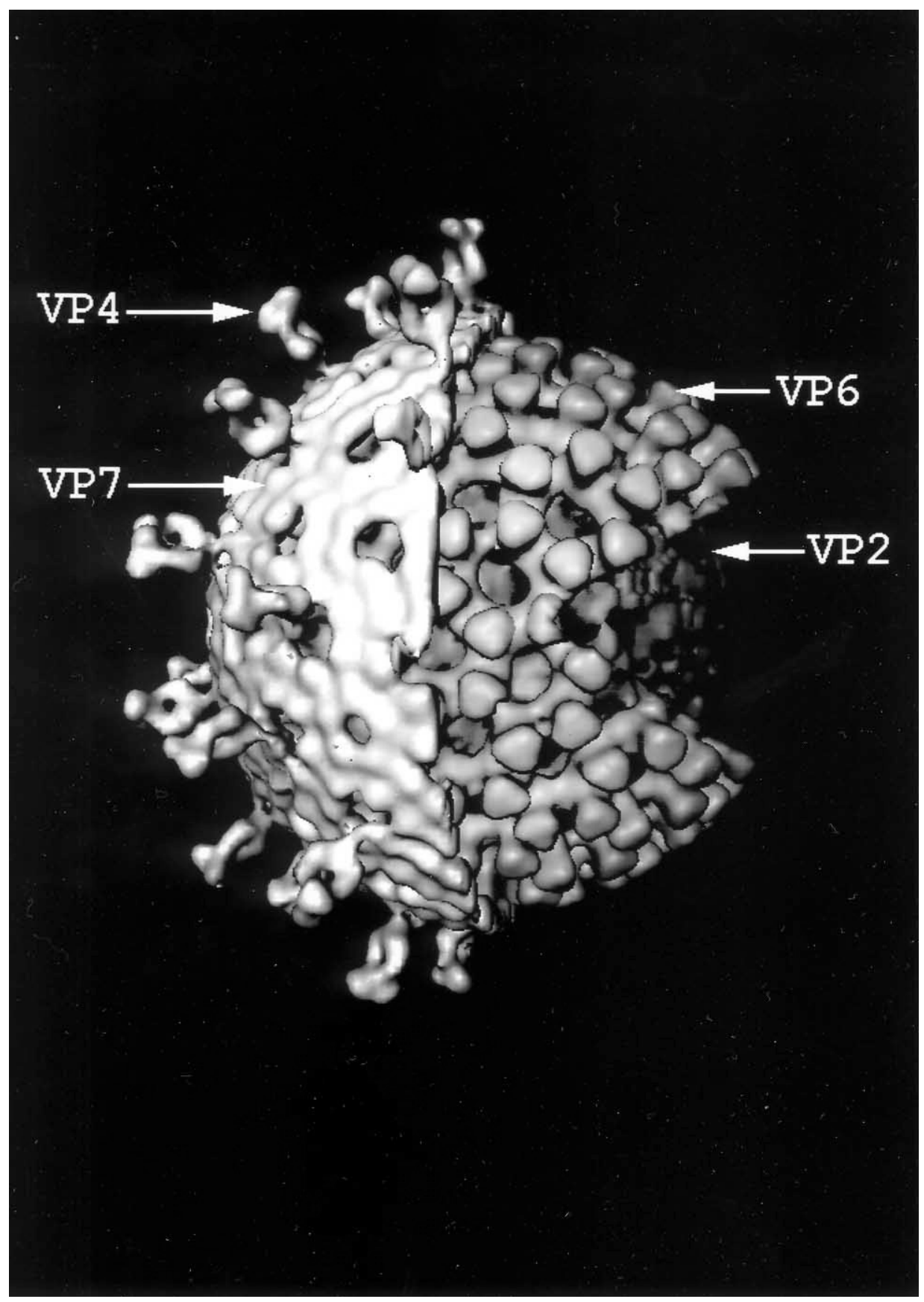

Figure I Computer-generated image of the triple-shelled rotavirus particle obtained by cryoelectron microscopy. The cut-away diagram shows the outer capsid composed of VP4 spikes and VP7 shell, intermediate VP6 shell, and innerVP2 shell surrounding the core containing the II double-stranded RNA segments and VPI and VP3 proteins. (Courtesy of Dr. B.V.V. Prasad, Baylor College of Medicine, Houston, TX.)

Wyatt et al 1982). When it was found later that VP4 could, in some cases, be the dominant neutralization protein (Ward et al 1988, 1993), a dual serotyping scheme was required. Although VP7 serotypes could be determined readily by cross-neutralization studies, this was more difficult for VP4 (Taniguchi et al 1988; Gorziglia et al 1990; Padilla-Noriega et al 1992; Snodgrass et al 1992). Therefore, two numeric systems were devised to classify the VP4 protein in rotavirus strains. One is based on comparative nucleic acid hybridization and sequence analyses (genotypes), and the second is based on neutralization (serotypes) using antisera against baculovirus-expressed VP4 proteins or reassortants with specific VP4 genes. Genotypes of VP4 are designated by brackets while serotypes are not. Rotavirus classification 
Table I Sizes of rotavirus gene segments and properties of encoded proteins

\begin{tabular}{|c|c|c|}
\hline $\begin{array}{l}\text { RNA } \\
\text { segment }\end{array}$ & $\begin{array}{l}\text { Encoded } \\
\text { protein }\end{array}$ & Properties of proteins \\
\hline I & VPI & $\begin{array}{l}\text { Inner core protein } \\
\text { RNA binding } \\
\text { RNA transcriptase }\end{array}$ \\
\hline 2 & VP2 & $\begin{array}{l}\text { Inner capsid protein } \\
\text { RNA binding }\end{array}$ \\
\hline 3 & VP3 & $\begin{array}{l}\text { Inner core protein } \\
\text { Guanylyltransferase } \\
\text { Methyltransferase }\end{array}$ \\
\hline 4 & VP4 & $\begin{array}{l}\text { Outer capsid protein } \\
\text { Hemagglutinin } \\
\text { Neutralization protein } \\
\text { Receptor binding } \\
\text { Fusogenic protein }\end{array}$ \\
\hline 5 & NSPI & $\begin{array}{l}\text { Nonstructural protein } \\
\text { RNA binding } \\
\text { IRF regulatory protein }\end{array}$ \\
\hline 6 & VP6 & $\begin{array}{l}\text { Intermediate capsid } \\
\text { Group and subgroup antigen }\end{array}$ \\
\hline 7 & NSP3 & $\begin{array}{l}\text { Nonstructural protein } \\
\text { RNA binding } \\
\text { Translational control }\end{array}$ \\
\hline 8 & NSP2 & $\begin{array}{l}\text { Nonstructural protein } \\
\text { RNA and NSP5 binding } \\
\text { Virosome formation }\end{array}$ \\
\hline 9 & VP7 & $\begin{array}{l}\text { Outer capsid glycoprotein } \\
\text { Neutralization protein }\end{array}$ \\
\hline 10 & NSP4 & $\begin{array}{l}\text { Nonstructural glycoprotein } \\
\text { Transmembrane protein } \\
\text { Enterotoxin }\end{array}$ \\
\hline II & NSP5 & $\begin{array}{l}\text { Nonstructural protein } \\
\text { Phosporylated } \\
\text { NSP2 and NSP6 binding }\end{array}$ \\
\hline 12 & NSP6 & $\begin{array}{l}\text { Nonstructural protein } \\
\text { NSP5 binding }\end{array}$ \\
\hline
\end{tabular}

Modified from Estes and Kapikian (2007).

based on VP4 and VP7 is designated P and G types to describe the protease sensitivity and glycosylated structure of these two proteins, respectively. Thus, the full designation for the most common serotype/genotype of human rotavirus is G1P1A[8]. Today, $15 \mathrm{G}$ types and $26 \mathrm{P}$ types have been described but only 5 G serotypes (G1, G2, G3, G4, and G9) and $3 \mathrm{P}$ genotypes (P[4], $\mathrm{P}[6]$, and $\mathrm{P}[8]$ ) are commonly associated with human rotavirus illnesses.

\section{Mechanisms of immunity to rotavirus}

An obvious place to begin to understand rotavirus immunity is to determine the effectiveness of previous rotavirus infections in prevention of subsequent infections and disease.
Many investigators have reported that natural rotavirus infections in humans produce incomplete protection, but little doubt exists that previous infections protect against severe disease associated with reinfection. In probably the most thorough study reported, protection against both reinfection and diarrhea increased with each new rotavirus infection but protection against severe rotavirus disease was nearly complete after a single rotavirus infection, even in the face of several circulating $G$ serotypes of the virus (Velazquez et al 1996). Sequential infections even with the same serotype clearly occur but less regularly than with different serotypes. Thus, there is conflicting data regarding the association between serotype-specific neutralizing antibody and protection. Active immunity against both homotypic and heterotypic rotaviruses has also been demonstrated in mice, calves, and rabbits after single rotavirus infections, further indicating something in addition to neutralizing antibody is important in protection (Bridger and Oldham 1987; Woode et al 1987; Ward et al 1992; Conner et al 1993)

The immunological effectors that prevent rotavirus disease have been partially identified, particularly through studies with animal models, but in humans remain poorly understood. Because rotaviruses replicate in intestinal enterocytes, resulting in the associated gastrointestinal symptoms, it is generally assumed that effector mechanisms must be active at the intestinal mucosa. The most obvious immunological effector is secretory IgA. In agreement with this suggestion, protection against rotavirus infection in orally immunized mice was found to correlate with levels of fecal and serum rotavirus IgA but not serum rotavirus IgG (Feng et al 1994; McNeal et al 1994). In humans, titers of serum and intestinal rotavirus IgA as well as serum rotavirus IgG were reported to correlate with protection following natural infection (Chiba et al 1986; Ward et al 1989; Clemens et al 1992; Coulson et al 1992; Matson et al 1993; O'Ryan et al 1994; Velazquez et al 2000).

The most immunogenic rotavirus protein is VP6 but it does not stimulate neutralizing antibodies. It has been reported, however, that IgA antibodies directed at VP6 can be protective by mechanisms that are not completely understood but may involve intracellular inhibition of rotavirus replication within infected enterocytes during polymeric antibody transport to the intestinal lumen (Burns et al 1996; Feng et al 2002; Corthesy et al 2006). Antibodies directed at either the VP4 or the VP7 proteins can neutralize virus and are believed to provide protection by classical neutralization. Both proteins can also induce type-specific and cross-reactive serotype responses (Mackow et al 1988; Morita et al 1988; Taniguchi et al 1988; Gorziglia et al 1990). 


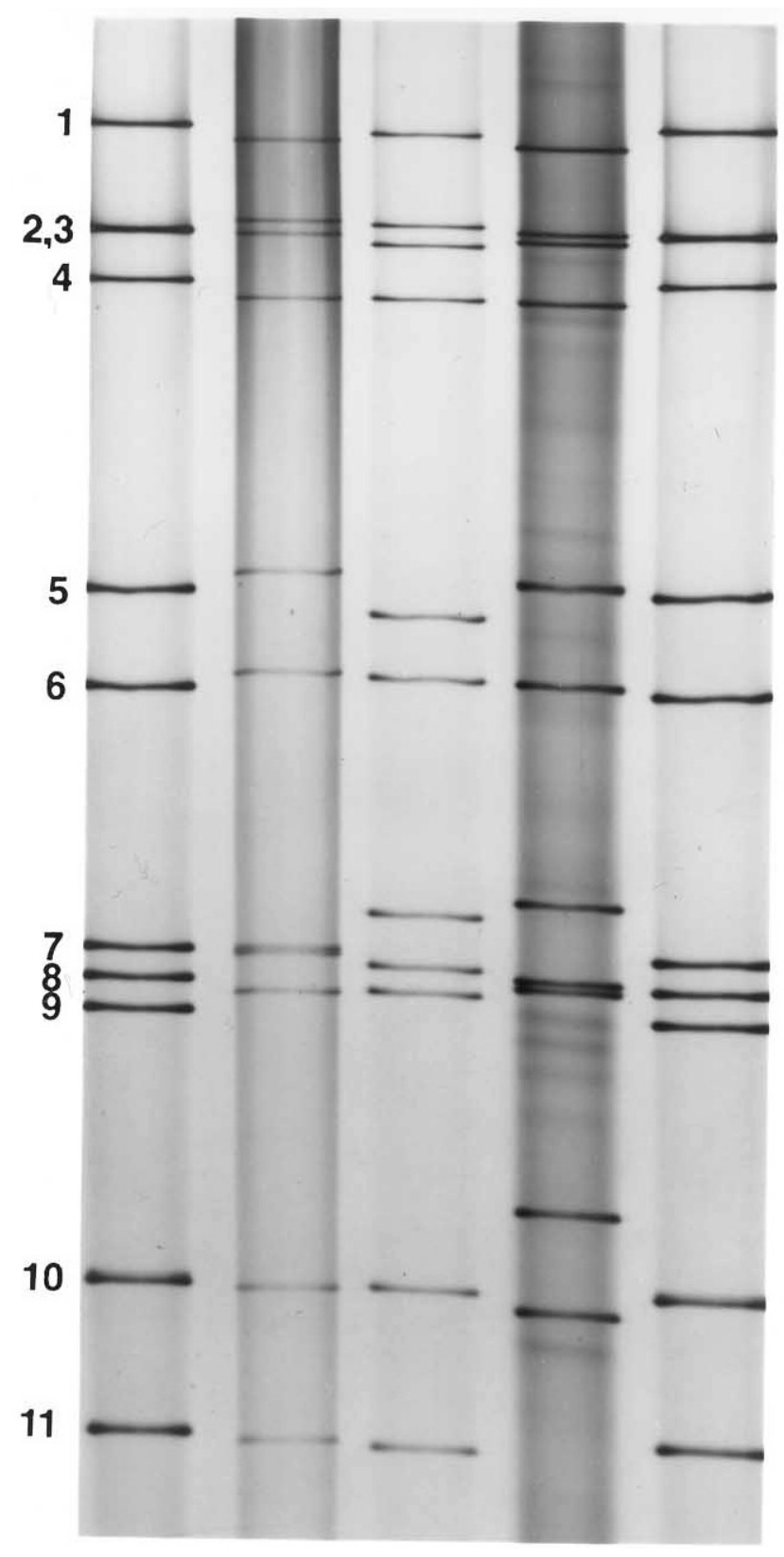

Figure 2 Polyacrylamide gel electrophoretic patterns of genomic RNAs obtained from group A human rotaviruses and visualized by silver staining. The patterns demonstrate the characteristic four size classes of RNA separated into groups of $4,2,3$, and 2 segments each. Human rotavirus strains included (from left to right) lane I,Wa; lane 2, 248 strain; lane 3, 456 strain; lane 4, DS- I; lane 5, Wa.

Gene knockout mice have been used to distinguish the roles of $\mathrm{CD} 8^{+} \mathrm{T}$ cells and antibody in protection. Rotavirusspecific cytotoxic $\mathrm{T}$ lymphocytes recognize epitopes on several rotavirus proteins which are generally not serotype specific (Offit and Dudzik 1988; Offit et al 1991; Franco et al 1994). Adoptive transfer of splenic lymphocytes from mice infected with homologous or heterologous rotavirus strains can protect suckling mice and protection appeared to depend on the presence of $\mathrm{CD} 8^{+} \mathrm{T}$ lymphocytes (Offit and Dudzik 1990). Similarly, $\mathrm{CD} 8^{+}$splenic or intraepithelial T lymphocytes obtained from the intestine of rotavirus-infected mice can eliminate the chronic rotavirus shedding seen in SCID mice (Dharakul et al 1990). Other studies revealed that adoptive transfer of splenic $\mathrm{CD} 4^{+} \mathrm{T}$ cells from mice intranasally immunized with a recombinant VP6 protein resolved shedding in chronically infected, immunodeficient Rag-2 mice (McNeal et al 2002). Therefore, either $\mathrm{CD} 8^{+}$or $\mathrm{CD}^{+} \mathrm{T}$ cells are capable of resolving rotavirus infections. Possible roles of these cells in resolution or prevention of human rotavirus infections remain to be determined.

Although cytolytic $\mathrm{CD} 8^{+}$cells were found to be important for resolution of a rotavirus infection, only antibody was shown to provide protection against a subsequent challenge (Franco and Greenberg 1995; McNeal et al 1995; Franco et al 1997). A recent study in mice revealed that oral immunization of mice with a rotavirus that was fully heterotypic to the challenge strain provided nearly complete protection against fecal rotavirus shedding but this protection was dependent on the ability of antibody to be transported through intestinal epithelial cells (VanCott et al 2006). This result supports the earlier suggestion that heterotypic protection after live virus immunization may be due to intracellular inhibition of virus replication, at least in mice (Burns et al 1996; Feng et al 2002; Corthesy et al 2006). These results indicate that the levels, location, and targets of antibody are all of immediate importance in protection against rotavirus. These findings have important implications for vaccine development

\section{Experiences gained from the early rotavirus vaccine candidates}

Because natural rotavirus infections induce excellent protection, at least against severe rotavirus disease, vaccine efforts have been directed mostly at the development of live attenuated rotavirus vaccines. Initial studies concentrated on the use of animal rotavirus strains, labeled the Jennerian approach (Kapikian et al 1986) because it relies on the natural attenuation of animal viruses in humans for safety, and largely heterotypic immune responses for protection. Just 10 years after the identification of rotavirus as the primary agent of severe diarrhea in young children, the first vaccine trials were performed using RIT 4237, a G6P[1] bovine rotavirus (Vesikari et al 1983). This vaccine was safe and effective in Finland, and provided protective efficacy of $>80 \%$ against severe rotavirus disease due to heterotypic human rotaviruses (Vesikari et al 1985). However, later studies in developing countries were disappointing, (DeMol et al 1986; Hanlon et al 1987; Lanata et al 1989) 
showing little or no efficacy, thus causing the termination of studies with this vaccine.

Initial studies with $\mathrm{WC} 3$, a G6P[5] bovine rotavirus developed as a vaccine candidate a short time later, also appeared promising (Clark et al 1988). However, subsequent trials did not show significant protection (Bernstein et al 1990; Georges-Courbot et al 1991), and studies with this candidate vaccine were also terminated. In an attempt to make the WC3 vaccine more serotypically related to human strains, genes encoding the VP4 and VP7 neutralization proteins from human rotaviruses were introduced into WC3 by gene reassortment. This method, labeled the modified Jennerian approach (Flores and Kapikian 1990), resulted in the development of the pentavalent RotaTeq ${ }^{\mathrm{TM}}$ vaccine, one of the two rotavirus vaccines being licensed in the world today.

A simian rotavirus called rhesus rotavirus (RRV) was also developed as one of the first vaccine candidates but protection elicited by this vaccine was likewise inconsistent (Flores et al 1987; Vesikari et al 1990; Santosham et al 1991; Madore et al 1992; Padilla-Noriega et al 1992). The G serotype of the G3P[3] RRV strain is shared with human rotaviruses and can be the dominant circulating strains, and protection elicited by RRV appeared to be more effective when this was the case. As a result, RRV was reassorted with human strains to incorporate VP7 genes of the other three dominant human G serotypes (G1, G2, and G4), thus creating the tetravalent Rotashield ${ }^{\mathrm{TM}}$ vaccine (Figure 3 ). This vaccine was licensed and incorporated into the USA infant immunization program in 1998 but was withdrawn by its manufacturer in 1999 after the discovery of a small but significant increase in intussusception in vaccinees during post-licensure surveillance (Murphy et al 2003).

The only other vaccine candidate developed directly from an animal strain and tested in humans was the G10P[12] lamb strain. This virus was administered to $>1,000$ children (aged 6-24 months) in a Phase II trial with no evidence of side effects (GAVI 2001). Although no controlled efficacy trials with this vaccine have been reported, it is presently licensed and being sold in the private market in China.

\section{Two rotavirus vaccines are being licensed worldwide today}

The first licensure of a rotavirus vaccine after the withdrawal of Rotashield in 1999 occurred in Mexico in 2004 and the vaccine became available there in January, 2005. This was the attenuated human Rotarix ${ }^{\mathrm{TM}}$ vaccine that was produced by GlaxoSmithKline. Since that time, the vaccine has been licensed in nearly 100 countries, including those

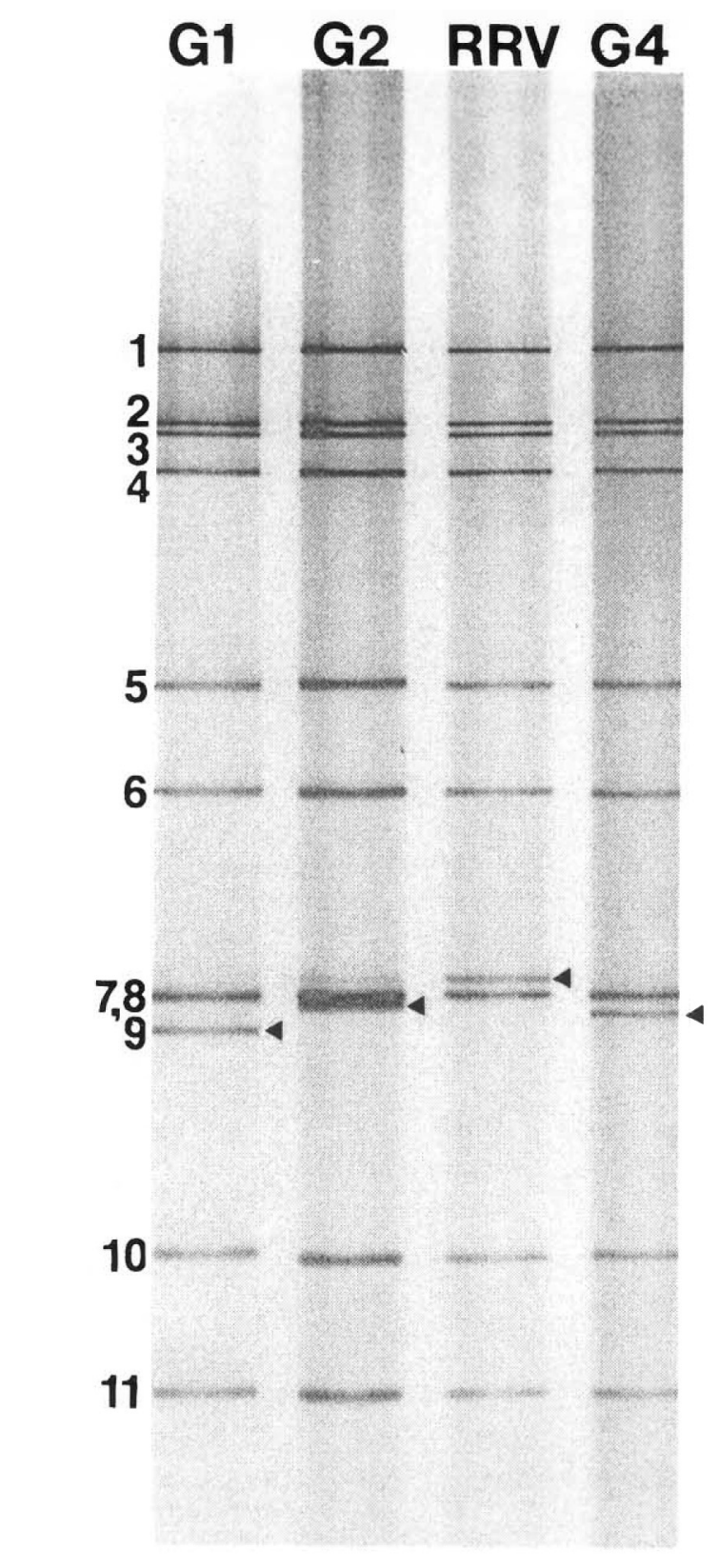

Figure 3 Polyacrylamide gel electrophoretic patterns of the genome segments from RRV and the GI, G2, and G4 reassortant strains that compose the tetravalent RRV-based vaccine (Rotashield). The strains all contain 10 RRV genes and differ only in the gene segment encoding the VP7 protein, which migrates in the seventh (RRV) or ninth (reassortants) position, as designated by arrowheads.

in the European Union, is being used in routine childhood vaccination in at least 7 nations, and has been pre-qualified for procurement by U.N. agencies by the World Health Organization. This vaccine is based on the attenuated human strain, 89-12, a G1P[8] strain which is the most common serotype worldwide. The virus was initially obtained from an infant with rotavirus gastroenteritis (Bernstein et al 1998), and attenuated by multiple passages in tissue culture. Studies showed the 89-12 vaccine was safe, although it induced a low 
grade fever in $19 \%$ of recipients, and two doses provided $89 \%$ protection against any rotavirus disease, and $100 \%$ protection from more serious disease (Bernstein et al 1999).

The 89-12 strain was purified by limiting dilution and further passaged in tissue culture. The final product, initially called RIX4414 and later marketed as Rotarix ${ }^{\mathrm{TM}}$, was evaluated in several studies. Initial safety testing (Vesikari, Karvonen, Korhonen et al 2004) revealed the vaccine was safe and did not induce the fever that was seen following vaccination with its 89-12 parent. Subsequent reports from Singapore (Phua et al 2005), Finland (Vesikari, Karvonen, Puustinen et al 2004), Latin America (Ruiz-Palacios et al 2006), and the USA (Dennehy et al 2005) confirmed the safety, verified the vaccine was not associated with fever, and reported that the vaccine remained highly immunogenic. Thus, the additional passages and/or limiting dilution purification resulted in a vaccine strain that has been consistently non-reactogenic. The vaccine also did not interfere with the immune responses to the other concomitantly used vaccines including OPV (Dennehy et al 2005; Ruiz-Palacios et al 2006). In the initial efficacy trial of RIX 4414 conducted in Finland over two rotavirus seasons, the vaccine was $73 \%$ protective against all rotavirus gastroenteritis and $90 \%$ protective against severe gastroenteritis despite the relatively low dose of vaccine used (Vesikari, Karvonen, Puustinen et al 2004).

Because of the association of Rotashield with intussusception, the next rotavirus vaccines were required to undergo very large safety trials. Rotarix was, therefore, evaluated in a very large safety trial (Ruiz-Palacios et al 2006). In a study of over 63,000 infants conducted primarily in several countries in Latin America, the vaccine was safe and did not induce fever and, most importantly, was not associated with intussusception. In this large study, efficacy was $85 \%$ against severe rotavirus diarrhea and hospitalizations, and reached $100 \%$ against more severe gastroenteritis. Of note, efficacy was high (over 86\%) against severe rotavirus diarrhea caused not only by G1P[8] strains but also by the VP4 related G3P[8], G4P [8] and G9P [8] strains. Efficacy against G2P[4] strains in the few subjects infected with these viruses was less, $41.0 \%$. However, in meta-analyses conducted with the data from several studies, the efficacy was $67 \%-71 \%$ indicating that the vaccine will be efficacious against strains that are serotypically dissimilar in both their VP4 and VP7 proteins (Ruiz-Palacios et al 2006; Vesikari, Karvonen, Korhonen, et al 2006). In the most recent trial of over 4,000 infants conducted in six European countries, protection was $87 \%$ against any rotavirus gastroenteritis, $96 \%$ against severe disease and $100 \%$ against hospitalization due to rotavirus (Vesikari, Karvonen, Korhonen et al 2006).
In this study, efficacies against $\mathrm{G} 3, \mathrm{G} 4$ and $\mathrm{G} 9$ rotaviruses were similar to that against G1 and exceeded $95 \%$ while efficacy against G2 strains was 75\%. Of importance, efficacy against hospitalization due to gastroenteritis of any cause was $75 \%$.

In 2006, the pentavalent WC3-based reassortant vaccine, Rotateq $^{\mathrm{TM}}$, was also licensed, first in the USA and subsequently in the European Union and other international settings by Merck. After the WC3 vaccine was shown to be safe but not consistently effective (Clark et al 1988; Bernstein et al 1990; Georges-Courbot et al 1991), a monovalent vaccine containing the VP7 protein of a human G1 rotavirus was developed. This vaccine was reported to be protective, especially against more severe disease, during a predominantly serotype G1 outbreak in the USA (Clark et al 1990; Treanor et al 1995). Next, a WC3-based reassortant quadrivalent vaccine including both VP7 and VP4 human rotavirus gene substitutions, ie, G1, G2, $\mathrm{G} 3$, or $\mathrm{P}[8]$, was evaluated. In studies conducted at multiple centers in the United States, it was shown to be safe and effective against all cases of rotavirus gastroenteritis (75\%) and especially against severe cases (100\%) (Clark et al 2004). The final pentavalent Rotateq vaccine contains the VP7 and VP4 reassortants found in the quadrivalent vaccine plus a VP7 G4 reassortant (Clark et al 2006).

Again, because of the association of Rotashield with intussusception, this rotavirus vaccine was also required to undergo very large safety trials. Accordingly, a study was conducted with RotaTeq in $>70,000$ infants, primarily in Finland and the USA, which showed that the vaccine was safe and induced no fever (Vesikari, Matson et al 2006). Most importantly, there was no association with intussusception. The vaccine was also highly effective, reducing all cases of G1-G4 rotavirus gastroenteritis by $74.0 \%$, severe gastroenteritis by $98.0 \%$, and hospitalizations and emergency room visits by $94.5 \%$. Interestingly, the efficacy of the vaccine against all gastroenteritis-related hospitalizations after the first dose was $58.9 \%$. Therefore, as was also found after Rotarix vaccination, overall protection against severe gastroenteritis seemed greater than expected based solely on rotavirus infections. Reasons for this have not been established but it is likely that either the percentage of hospitalizations due to rotavirus are greater than expected or vaccination provides a general boost in immunity that protects against more than just rotavirus disease.

\section{What alternative rotavirus vaccine candidates are being most actively investigated?}

Several other live, orally-deliverable rotavirus vaccine candidates are under development, some for many years, but these 
had not been put on the fast-track with Rotarix or RotaTeq. However, with new and improved funding from donor agencies along with greater national and international appreciation for the importance of rotavirus as a deadly pathogen, this picture is changing. In addition, several non-living rotavirus vaccine candidates have been developed and tested in animal models but none have been evaluated in humans. Studies on the best known live and non-living alternative rotavirus vaccine candidates will now be described along with the status of their development.

\section{Alternative live rotavirus vaccine candidates}

Although several live rotavirus vaccine candidates are under development for potential national or regional usage, three alternative candidates appear to presently have the most potential for broader usage (Table 2 ). These three [the bovine (UK strain)/human reassortant vaccine, the human neonatal RV3 strain, and the bovine/human neonatal 116E strain] have all been under development for many years, but progress with each has been delayed for its own unique reasons.

The bovine (UK) reassortant vaccine was developed in the laboratory of Albert Kapikian of the National Institutes of Health in Bethesda, Maryland, together with the RRV-based tetravalent vaccine that became Rotashield. One reason to concentrate on the simian rotavirus-based vaccine at the expense of the bovine rotavirus-based candidate was the serotypes of the two strains. The bovine strain was serotypically unrelated to relevant human rotaviruses while RRV shared its G serotype (G3) with one of the four dominant human rotavirus types. The decision to focus on the RRV strain had one of the greatest impacts of any made during rotavirus vaccine development. The RRV-based vaccine clearly had center-stage for years during the course of its evaluation, licensure, and subsequent incorporation into the childhood immunization series in the USA.

Even so, the tetravalent bovine (UK) reassortant vaccine, that contained single VP7 gene substitutions from G1, G2,

Table 2 Alternative live rotavirus vaccine candidates

\begin{tabular}{lll}
\hline Candidate & Origin & Status \\
\hline UK reassortant & $\begin{array}{l}\text { Developed at NIH } \\
\text { Bovine reassortant containing GI, } \\
\text { G2, G3, G4 human genes }\end{array}$ & $\begin{array}{l}\text { Phase I and } \\
\text { early Phase II }\end{array}$ \\
RV3 & $\begin{array}{l}\text { Human neonatal strain (G3P[6]) } \\
\text { isolated in Australia }\end{array}$ & $\begin{array}{l}\text { Phase I and } \\
\text { early Phase II }\end{array}$ \\
II6E & $\begin{array}{l}\text { Natural bovine-human reassortant } \\
(\mathrm{G} 9 \mathrm{P}[\mathrm{II}]) \text { isolated in India }\end{array}$ & $\begin{array}{l}\text { Phase I and } \\
\text { early Phase II }\end{array}$ \\
\hline
\end{tabular}

G3 or G4 human rotaviruses on a 10-gene UK background, was evaluated initially for safety and immunogenicity in the USA (Clements-Mann et al 1999) and later for safety/immunogenicity/efficacy in Finland (Vesikari, Karvonen, Majuri, et al 2006) before the withdrawal of Rotashield. Although the studies were small (161 vaccinees and 80 placebo recipients in the efficacy trial), protection was significant (60\% against any rotavirus disease and 90\% against severe rotavirus disease; $p<0.02$ ). In order to facilitate the production and commercialization of this vaccine, the NIH Office of Technology Transfer has granted licenses to at least 8 groups throughout the world, 7 of which are in developing nations, including vaccine manufacturers in Brazil, China and India.

$\mathrm{RV} 3$ is a G3P[6] human rotavirus that was isolated in an obstetric nursery in Melbourne, Australia, where it caused endemic, asymptomatic infections in newborn infants in the 1970s. Neonates infected with this virus were $100 \%$ protected against severe rotavirus disease, caused primarily by heterotypic G2P[4] strains, for their first 3 years of life (Bishop et al 1983). Once RV3 was developed into a vaccine candidate, Phase I and early Phase II trials were conducted (Barnes et al 2002). Although an immune response to the vaccine was detected in only $46 \%$ of subjects, protection in the responders against primarily serotype $\mathrm{G} 1$ circulating rotaviruses was $54 \%(\mathrm{p}=0.08)$. It has been suggested that vaccine "take" may be improved if the dose is increased above the $6.5 \times 10^{5}$ tissue culture infectious viruses previously administered. Accordingly, the virus has been grown to a higher titer and plans are underway for its evaluation after administration of higher doses. The slow pace at which this vaccine has been developed is presumably related to its somewhat disappointing immunogenicity and the lack of interest from pharmaceutical companies. Both limitations may be corrected with the use of a higher titer virus. Current plans include development of the vaccine candidate with a vaccine manufacturer in Indonesia.

The 116E G9P[11] rotavirus strain was obtained from neonates who became asymptomatically-infected in New Delhi, India, in the mid-1980's. Subjects who became infected were significantly $(\mathrm{p}<0.05)$ protected against subsequent rotavirus diarrhea (Bhan et al 1993). 116E is a natural reassortant, deriving it VP4 gene segment from a bovine rotavirus and the other 10 genes from a human strain (Das et al 1993, 1994). During the same period that the $116 \mathrm{E}$ strain was infecting neonates in New Delhi, another bovine/human reassortant was asymptomatically-infecting neonates in the Bangalore region of India. The G10PI I321 
strain isolated from these subjects derived 9 gene segments from a bovine rotavirus and only the segments for 2 nonstructural genes from a human strain (Dunn et al 1993). It was initially suggested that neonates infected with G10P[11] strains appeared to be protected against subsequent rotavirus disease (Aijaz et al 1996), but a very recent report by another group of investigators suggests otherwise (Banerjee et al 2007). Regardless, the I321 strain was also developed into a vaccine candidate. However, when both $116 \mathrm{E}$ and I321 vaccines were tested for immunogenicity in a small, placebo-controlled trial, only the $116 \mathrm{E}$ strain was found to elicit significant immune responses (Bhandari et al 2006). Therefore, the I321 strain was shelved and only the $116 \mathrm{E}$ strain is now being actively pursued as a vaccine candidate. Although vaccine preparations of both candidates were prepared and initial human trials were initiated in Cincinnati, Ohio, in 1997, these trials were discontinued in 1998 due to concerns over the purity of the cells in which the vaccines were grown. These concerns were eventually alleviated and only then were trials with these vaccines continued, this time in India where the viruses were first discovered (Bhandari et al 2006).

\section{Non-living rotavirus vaccine candidates}

The original expectation for successful live, orally-deliverable rotavirus vaccines was that they protect against almost all cases of rotavirus disease of any severity. This expectation has been modified with the realization that even natural rotavirus infections do not provide complete protection against subsequent rotavirus illnesses. However, one natural infection has been reported to provide nearly complete $(87 \%)$ protection against severe rotavirus disease and two infections were $100 \%$ protective (Velazquez et al 1996). Therefore, a more realistic goal for a successful live rotavirus vaccine is that it is able to consistently provide a high level of protection against severe rotavirus illnesses. This goal has so far been realized, where tested, for the rotavirus vaccines now being licensed and had been found for the Rotashield vaccine as well. However, no efficacy trials with any of these three vaccines have been completed in Third World nations where rotavirus deaths are most common and where the earlier rotavirus vaccine candidates failed to provide significant protection.

Based on these observations regarding efficacies and the not fully resolved safety concerns associated with live rotavirus vaccines, non-living rotavirus vaccines are being developed as possible next generation candidates. Although these range from fully intact, inactivated rotaviruses to pieces of rotavirus proteins, even to DNA vaccines, three types of candidates have been given the most attention. These include inactivated triple- and double-layered (lacking VP4 and VP7) rotavirus particles, triple- and double-layered viruslike particles (VLPs), and recombinant, E. coli-expressed VP6 proteins (Table 3). Candidates representative of each of these 3 types have been under development since the 1980s and tested in animal models but, as already noted, none have been evaluated in humans.

Vaccination with inactivated rotavirus particles delivered by either parenteral or mucosal (intranasal) routes has been found to effectively block intestinal rotavirus replication in adult mice challenged with a murine rotavirus (McNeal et al 1998, 1999). In most cases, protection was enhanced

Table 3 Alternative non-living rotavirus vaccine candidates

\begin{tabular}{|c|c|c|c|}
\hline Candidate & Properties & Where tested & Level of protection \\
\hline Inactivated virus & $\begin{array}{l}\text { Viral particles inactivated } \\
\text { by physical or chemical } \\
\text { methods }\end{array}$ & $\begin{array}{l}\text { Tested in mice, } \\
\text { rabbits and } \\
\text { gnotobiotic piglets }\end{array}$ & $\begin{array}{l}\text { Effective in reducing or } \\
\text { preventing rotavirus shedding } \\
\text { with or without the use of } \\
\text { adjuvants. }\end{array}$ \\
\hline $\begin{array}{l}\text { Virus like particles } \\
\text { (VLPs) }\end{array}$ & $\begin{array}{l}\text { Particles formed from } \\
\text { expressed recombinant } \\
\text { proteins. Contain VP2 and } \\
\text { VP6 with or without VP4 } \\
\text { and VP7 }\end{array}$ & $\begin{array}{l}\text { Tested in mice, } \\
\text { rabbits and } \\
\text { gnotobiotic pigs }\end{array}$ & $\begin{array}{l}\text { Effective in reducing or } \\
\text { preventing rotavirus shedding } \\
\text { in mice and rabbits. Alone, } \\
\text { not protective in gnotobiotic } \\
\text { piglets. More effective with } \\
\text { an adjuvant. More effective } \\
\text { intranasally than orally. }\end{array}$ \\
\hline VP6 & $\begin{array}{l}\text { E. coli-expressed } \\
\text { recombinant protein }\end{array}$ & Tested in mice & $\begin{array}{l}\text { Effective in reducing or } \\
\text { preventing rotavirus shedding } \\
\text { when given orally, } \\
\text { intranasally or intrarectally } \\
\text { with adjuvant to mice. }\end{array}$ \\
\hline
\end{tabular}


by co-immunization with an effective adjuvant. Fully intact, triple-layered particles were found to be more effective than double-layered particles only when their VP4 or VP7 protein matched the serotype of the challenge virus. This suggested that neutralizing antibodies played a role in protection but were not required for effective immunity. One formaldehydeinactivated, purified rotavirus vaccine candidate, prepared from the G1P[4] AU64 strain, has been used to intramuscularly immunize gnotobiotic piglets which were reported to be protected from fecal virus shedding following challenge with a G1P [8] human rotavirus (O. Nakagomi personal communication). Other candidate vaccines were prepared by the Viral Gastroenteritis Laboratory of the Centers for Disease Control (Atlanta, GA), including G1P[8], G2P [4] and G9P [6] strains, and studies are being performed to determine their immunogenicities and efficacies in mice, macaques, and gnotobiotic piglets (B Jiang personal communication).

The premier laboratory for studies on immunity and efficacy involving rotavirus immunization in gnotobiotic piglets has been that of Linda Saif (The Ohio State University, Wooster, $\mathrm{OH}$ ), and one candidate vaccine that has been evaluated in her laboratory is the inactivated G1P [8] Wa strain of human rotavirus. Reports from these studies indicate that after either oral or intramuscular delivery of inactivated Wa to newborn piglets, intestinal IgA responses to the immunogen, as well as protection against intestinal fecal rotavirus production and diarrhea after challenge with virulent Wa virus, were significantly less than found after oral vaccination with live Wa virus (To et al 1998; Yuan and Saif 2002). However, protection in this piglet model has been consistently less effective with all immunogens tested than found in adult mice. There are several explanations for this observation but, in the end, it will not be clear which model is more applicable to humans until the studies are performed in humans.

VLPs have been developed as possible vaccine candidates for several viruses, and production of rotavirus VLPs was first reported in the 1980s (Estes et al 1984; Ready and Sabara 1987; Crawford et al 1994). Any of several expression vectors can be used to produce the recombinant proteins that become incorporated into VLPs, but the most common is baculovirus and has been the expression vector of choice for rotavirus as well. One of the most viable candidate rotavirus vaccines in the early 1990's was composed of VLPs which underwent extensive preclinical testing. However, following several changes in ownership due to company acquisitions, this VLP vaccine was eventually licensed by the same company that was developing Rotashield. No significant clinical progress with this or any other rotavirus VLP vaccine has occurred since that time but studies in animal models with candidate VLP vaccines have flourished. Some VLP vaccines contain only VP2 and VP6 (2/6 VLPs) while others have incorporated one or more of the neutralization proteins, VP4 and VP7 (2/6/4/7 VLPs). Many recent animal studies have utilized 2/6 VLPs administered by mucosal routes together with effective adjuvants. Both intranasal and intrarectal immunization of mice with these particles has resulted in excellent protection against fecal rotavirus shedding following murine rotavirus challenge (O’Neal et al 1997, 1998; Agnello et al 2006). Intrarectal immunization of mice with VLPs containing the VP8* portion of VP4 along with VP2, VP6 and VP7 also provided excellent protection in mice (Parez et al 2006). In contrast, gnotobiotic piglets intranasally-immunized with 2/6 VLPs were neither protected against fecal shedding of the challenge virus (virulent Wa) nor diarrheal illness (Yuan et al 2000). Subsequent studies in piglets suggested that 2/6 VLPs with adjuvant would supplement protection if given as a booster following an initial immunization with attenuated Wa virus (Nguyen et al 2006). VLP rotavirus vaccines have also been delivered intramuscularly to both mice and rabbits where they produced effective protection against fecal shedding (Bertolotti-Ciarlet et al 2003; Ciarlet et al 1998). Although protection induced by $2 / 6$ VLPs in rabbits was enhanced by inclusion of VP4, this was not required for mice.

Vaccine candidates composed only of chimeric, E. coliexpressed VP6 proteins from murine or human rotaviruses have been found to effectively protect mice against fecal rotavirus shedding when administered either intranasally, orally or intrarectally with effective adjuvants (Choi et al 1999, 2002). The level of protection has been consistently $>90 \%$ by any of these routes and protection was found to remain fully intact for at least one year. VP6 is the group antigen and, therefore, is highly conserved within group A rotaviruses. Thus, it is not surprising that protection elicited by intranasal immunization of adult mice with a human rotavirus VP6 protein was highly protective against fecal rotavirus shedding following challenge with heterotypic murine rotaviruses. Interestingly, protection elicited by intranasal immunization of neonatal mice with VP6 and adjuvant was delayed but eventually reached the level found after immunization of adult mice, a finding that may have relevance if this vaccine were administered to human neonates (VanCott et al 2006).

Although anti-rotavirus antibodies have been identified as the primary effectors of protection after oral immunization 
with live rotaviruses (Franco and Greenberg 1995; McNeal et al 1995; VanCott et al 2006), this was not the case following mucosal immunization with VP6 and adjuvant. In this case, the only lymphocytes found to be required for protection were $\mathrm{CD}^{+} \mathrm{T}$ cells (McNeal et al 2002). Protection elicited by these effector cells was found to be associated with the intestinal production of two cytokines, IL-17 and IFN $\gamma$ (Smiley et al 2007), thus suggesting these cytokines may have direct or indirect roles in protection against rotavirus shedding. However, even in genetically-modified mice that cannot, individually, make these proteins, full protection is still elicited after intranasal immunization with VP6 and adjuvant. Therefore, neither of these cytokines is required for protection, thus leaving the identity of the actual effectors of protection in doubt. Protection induced after intranasal immunization of mice with 2/6 VLPs was also reported to depend on $\mathrm{CD}^{+} \mathrm{T}$ cells (Blutt et al 2006). Thus, the primary effectors responsible for protection after oral immunization with live rotavirus and at least 2 of the non-living candidate vaccines appear to be quite different.

Although some of the most promising alternative rotavirus vaccine candidates for future development and evaluation are those classified as non-living, there has been little consistent interest in, and funding available for, making this happen. The main reasons appear to be the lack of human clinical trial knowledge and the costs that are perceived to be needed to bring a non-living rotavirus vaccine into the marketplace. Presumably this would change dramatically if the use of another live rotavirus vaccine were stopped due to an unacceptable safety problem, something that no one wants.

\section{Why are alternative rotavirus vaccines needed?}

This question is one that when answered by 100 experts, will generate at least 90 different answers, all shaded in various ways to reflect the particular experience and current position of the responder. Recognition of that will better allow the reader to incorporate statements made here on this question into their own experience before drawing conclusions. There are several historical facts that should be considered before addressing this question. The first is that during the development and licensing of Rotashield, development of other rotavirus vaccine candidates was on the distant horizon. Thus, the disappointment associated with its withdrawal from the USA market in 1999 was accentuated. The next rotavirus vaccine to be licensed was Rotarix in Mexico and its distribution was not begun until 2005. Thus, co-development of multiple candidate rotavirus vaccines seemingly would have reduced this hiatus period.
However, the removal of any vaccine due to a safety issue would undoubtedly trigger a series of reactions that would affect other candidates, resulting in extended testing and delays in their licensure, and the greater the similarity of the two products, the greater would be the expected delay. Thus, even if either Rotarix or RotaTeq were approaching licensure in 1999, it was inevitable that much larger studies would have had to have been performed with these candidates to minimize the chances that they would also trigger intussusception. Presumably, other types of rotavirus vaccines, such as non-living candidates, would have come under less scrutiny regarding the same specific concern. However, that is not even certain. What does seem clear is that if another live, orally-deliverable rotavirus vaccine candidate is found to trigger intussusception, this entire class of vaccine candidates may be in jeopardy. This is why it was imperative that the two new rotavirus vaccines could not be licensed until it was established that the potential risk that they trigger intussusception has been investigated and minimized. It remains unclear if a similar burden for large safety trials, as undertaken by the developers of Rotarix and RotaTeq will be expected of the developers of any new rotavirus vaccine candidates (eg, the UK bovine/human reassortant or the two human neonatal strains), a situation that may be very difficult for the new manufacturers to support.

After reviewing the data generated in the two large safety studies (Ruiz-Palacios et al 2006; Vesikari, Karvonen, Majuri et al 2006), the WHO Global Committee for Vaccine Safety (GACVS) concluded that the licensed vaccines were safe within these clinical trial settings, ie, where the vaccines were given strictly according to a young age. However, the GACVS strongly recommended that post-marketing surveillance for safety should be conducted in countries planning to introduce these vaccines. In addition, it was noted that strict compliance with a young age of administration in many developing countries would be extremely difficult to implement. Therefore, the question of safety with regards to intussusception of live attenuated oral rotavirus vaccines, as a class action effect, remains unanswered today.

Another historical point of importance regarding the need for alternative rotavirus vaccines is financial. Certainly a purpose of the manufacturers of Rotarix and RotaTeq is to make a profit and both have spent large amounts to reach where they are today. To recover their costs of development, they cannot give away their vaccines. Tiered pricing is already in effect as witnessed by the comparison of the cost of Rotarix in the private market of Europe vs. the public market in Brazil. Merck has indicated that RotaTeq will be available 
at cost to countries in the developing world. However, even the price charged in Brazil will be unmanageable by most Third World nations unless the expense is supplemented by a donor agency such as the Global Alliance for Vaccines and Immunization (GAVI).

Three recent global developments have accelerated this supplementation process. First, the decision by the WHO to recommend rotavirus vaccine introduction in regions of the world where the clinical efficacy of the vaccines have been demonstrated, ie, essentially in Latin America and Europe; secondly, the WHO approval of pre-qualification status for Rotarix, with RotaTeq pre-qualification likely during 2007; and thirdly, the decision by the GAVI Board to endorse funding for rotavirus vaccine purchase and introduction in resource poor countries in the regions recommended by WHO. All these developments contribute to help GAVI and UNICEF to purchase vaccines in those regions for eligible countries. However, at some point, this support is expected to cease and the nations themselves will be expected to pay the costs after the time of hand-over. The questions then are what will be these costs and will the poor nations be able to pay them? Historically, competition has driven down prices and there are ample examples of this with international vaccines. Thus, the development of alternative rotavirus vaccines could have this effect, especially if they were made in the developing nations themselves. This is at least one factor that has contributed to the funding of the $116 \mathrm{E}$ and UK bovine/human reassortant vaccine candidates in developing nations. Perhaps the eventual production of these or other candidate vaccines will drive down prices. Since the costs associated with the production of rotavirus vaccines will be related to their site of production, it is possible that if Rotarix or RotaTeq were produced in developing nations it could also help reduce the prices of these two vaccines. However, this would provide limited capacity building to the developing nation, a factor that is likely to less effectively control prices and continue the dependence of these nations on large pharmaceutical companies typically located in developed nations. It is also possible that the large multinational companies may be unable to supply all the rotavirus vaccine needed to immunize the world's babies, something that is envisioned as necessary if the deaths due to rotavirus disease, $90 \%$ of which occur in these poor countries, are to be seriously curtailed. Local manufacturers in developing nations could make large contributions toward this end. Furthermore, the three countries with the largest birth cohorts (China, India and Indonesia) and with high rotavirus mortality do not classically import new vaccines. Thus, if alternative effective rotavirus vaccines were produced, licensed and made available only in these countries, there would still be a significant reduction in rotavirus mortality globally.

Another question regarding alternative rotavirus vaccines now under development is whether they are significantly different from the two being licensed today. Two of them (RV3 and 116E) are monovalent human rotavirus vaccines while the UK bovine/human reassortant vaccine is polyvalent. Thus, the first two are more similar to Rotarix and the latter is similar to RotaTeq. Certainly the serotypes of the monovalent vaccines differ from the G1P[8] Rotarix strain and this or other properties of these strains could affect their individual safety, immunogencity and efficacy features. These possible differences between monovalent vaccine candidates cannot be dismissed, just as potential differences between the properties of the bovine reassortant vaccines cannot be disregarded. However, it seems unlikely that any of the alternative candidates will offer significant improvements unless, for example, the reassortant UK bovine vaccine contains additional reassortant viruses not present in RotaTeq that are representative of emerging serotypes. Perhaps the use of a different immunization schedules with the alternative candidates, such as neonatal immunization, may increase their efficacies over those of Rotarix and RotaTeq, but there is no data to support this hypothesis.

\section{Planning for the future}

The primary purpose of the "Meeting on Upstream Rotavirus Vaccines and Emerging Vaccine Producers" held at the WHO Headquarters in Geneva in March of 2006 was to obtain a consensus of opinion among many of the world leaders in rotavirus vaccine development regarding the need for alternative rotavirus vaccines and which should be given priority. Presentations were given by representatives of the companies (Merck and GlaxoSmithKline) that are manufacturing the two licensed vaccines being marketed worldwide today as well as by representatives of alternative living and non-living candidate rotavirus vaccines that are under development and developing world manufacturers who are potential producers of these vaccines. Upon closure of the meeting, there was general agreement that alternative vaccines are needed but the priority of reasons among attendees was highly variable. Although almost all clinical monies and efforts have been and are continuing to be directed toward live rotavirus vaccines, scientific logic suggests serious attention should be given to the non-living candidates. Opinions regarding prioritization of even the different live rotavirus vaccine candidates also 
varied, thus leaving their future funding and development uncertain. In the end, the field will move forward, new vaccines will be developed, and world coverage will occur. The questions that remain are how long will this take and with what rotavirus vaccines.

\section{References}

Adams WR, Kraft LM. 1963. Epizootic diarrhea of infant mice: indentification of the etiologic agent. Science, 141:359-60.

Agnello D, Herve CA, Lavaux A, et al. 2006. Intrarectal immunization with rotavirus $2 / 6$ virus-like particles induces an antirotavirus immune response localized in the intestinal mucosa and protects against rotavirus infection in mice. $J$ Virol, 80:3823-32.

Aijaz S, Gowda K, Jagannath HV, et al. 1996. Epidemiology of symptomatic human rotaviruses in Bangalore and Mysore, India, from 1988 to 1994 as determined by electropherotype, subgroup and serotype analysis. Arch Virol, 141:715-26.

Banerjee I, Gladstone BP, Le Fevre AM, et al. 2007. Neonatal infection with $\mathrm{G} 10 \mathrm{P}[11]$ rotavirus did not confer protection against subsequent rotavirus infection in a community cohort in Vellore, South India. J Infect Dis, 195:625-32.

Barnes GL, Lund JS, Mitchell SV, et al. 2002. Early phase II trial of human rotavirus vaccine candidate RV3. Vaccine, 20:2950-6.

Bernstein DI, Sack DA, Rothstein E, et al. 1999. Efficacy of live, attenuated, human rotavirus vaccine 89-12 in infants: a randomised placebocontrolled trial. Lancet, 354:287-90.

Bernstein DI, Smith VE, Sander DS, et al. 1990. Evaluation of WC3 rotavirus vaccine and correlates of protection in healthy infants. $J$ Infect Dis, 162:1055-62.

Bernstein DI, Smith VE, Sherwood JR, et al. 1998. Safety and immunogenicity of live, attenuated human rotavirus vaccine 89-12. Vaccine, 16:381-7.

Bertolotti-Ciarlet A, Ciarlet M, Crawford SE, et al. 2003. Immunogenicity and protective efficacy of rotavirus $2 / 6$-virus-like particles produced by a dual baculovirus expression vector and administered intramuscularly, intranasally, or orally to mice. Vaccine, 21:3885-900.

Bhan MK, Lew JF, Sazawal S, et al. 1993. Protection conferred by neonatal rotavirus infection against subsequent rotavirus diarrhea. $J$ Infect Dis, $168: 282-7$

Bhandari N, Sharma P, Glass RI, et al. 2006. Safety and immunogenicity of two live attenuated human rotavirus vaccine candidates, $116 \mathrm{E}$ and I321, in infants: results of a randomised controlled trial. Vaccine, 24:5817-23.

Bishop RF, Davidson GP, Holmes IH, et al. 1973. Virus particles in epithelial cells of duodenal mucosa from children with acute non-bacterial gastroenteritis. Lancet, 2:1281-3.

Blutt SE, Warfield KL, Estes MK, et al. 2006. Immunity to rotavirus requires CD4+ T cells. In "9th dsRNA Virus Symposium", Cape Town, South Africa.

Bridger JC. 1980. Detection by electron microscopy of caliciviruses, astroviruses and rotavirus-like particles in the faeces of piglets with diarrhoea. Vet Rec, 107:532-3.

Bridger JC, Oldham G. 1987. Avirulent rotavirus infections protect calves from disease with and without inducing high levels of neutralizing antibody. J Gen Virol, 68:2311-17.

Burns JW, Siadat-Pajouh M, Krishnaney AA, et al. 1996. Protective effect of rotavirus VP6-specific IgA monoclonal antibodies that lack neutralizing activity. Science, 272:104-7.

Cheever FS, Mueller JH. 1947. Epidemic kiarrheal disease of suckling mice I. Manifestations, epidemiology, and attempts to transmit the disease. $J$ Exp Med, 85:405-16.

Chiba S, Yokoyama T, Nakata S, et al. 1986. Protective effect of naturally acquired homotypic and heterotypic rotavirus antibodies. Lancet, 2:417-21.
Choi AH, Basu M, McNeal MM, et al. 1999. Antibody-independent protection against rotavirus infection of mice stimulated by intranasal immunization with chimeric VP4 or VP6 protein. J Virol, 73:7574-81

Choi AH, McNeal MM, Basu M, et al. 2002. Intranasal or oral immunization of inbred and outbred mice with murine or human rotavirus VP6 proteins protects against viral shedding after challenge with murine rotaviruses. Vaccine, 20:3310-21.

Ciarlet M, Crawford SE, Barone C, et al. 1998. Subunit rotavirus vaccine administered parenterally to rabbits induces active protective immunity. J Virol, 72:9233-46.

Clark HF, Bernstein DI, Dennehy PH, et al. 2004. Safety, efficacy, and immunogenicity of a live, quadrivalent human-bovine reassortant rotavirus vaccine in healthy infants. J Pediatr, 144:184-90.

Clark HF, Borian FE, Bell LM, et al. 1988. Protective effect of WC3 vaccine against rotavirus diarrhea in infants during a predominantly serotype 1 rotavirus season. $J$ Infect Dis, 158:570-87.

Clark HF, Borian FE, Plotkin SA. 1990. Immune protection of infants against rotavirus gastroenteritis by a serotype 1 reassortant of bovine rotavirus WC3. J Infect Dis, 161:1099-104.

Clark HF, Offit PA, Plotkin SA, et al. 2006. The new pentavalent rotavirus vaccine composed of bovine (strain WC3) -human rotavirus reassortants. Pediatr Infect Dis J, 25:577-83.

Clemens JD, Ward RL, Rao MR, et al. 1992. Seroepidemiologic evaluation of antibodies to rotavirus as correlates of the risk of clinically significant rotavirus diarrhea in rural Bangladesh. $J$ Infect Dis, 165:161-5.

Clements-Mann ML, Makhene MK, Mrukowicz J, et al. 1999. Safety and immunogenicity of live attenuated human-bovine (UK) reassortant rotavirus vaccines with VP7-specificity for serotypes 1,2, 3 or 4 in adults, children and infants. Vaccine, 17:2715-25.

Conner ME, Crawford SE, Barone C, et al. 1993. Rotavirus vaccine administered parenterally induces protective immunity. $J$ Virol, 67:6633-41.

Corthesy B, Benureau Y, Perrier C, et al. 2006. Rotavirus anti-VP6 secretory immunoglobulin A contributes to protection via intracellular neutralization but not via immune exclusion. J Virol, 80:10692-9.

Coulson BS, Grimwood K, Hudson IL, et al. 1992. Role of coproantibody in clinical protection of children during reinfection with rotavirus. $J$ Clin Microbiol, 30:1678-84.

Crawford SE, Labbe M, Cohen J, et al. 1994. Characterization of virus-like particles produced by the expression of rotavirus capsid proteins in insect cells. $J$ Virol, 68:5945-52.

Das BK, Gentsch JR, Cicirello HG, et al. 1994. Characterization of rotavirus strains from newborns in New Delhi, India. J Clin Microbiol, 32:1820-2.

Das M, DunnSJ, Woode GN, et al. 1993. Both surface proteins (VP4 and VP7) of an asymptomatic neonatal rotavirus strain (I321) have high levels of sequence identity with the homologous proteins of a serotype 10 bovine rotavirus. Virology, 194:374-9.

de Zoysa I, Feachem RG. 1985. Interventions for the control of diarrhoeal diseases among young children: rotavirus and cholera immunization. Bull World Health Organ, 63:569-83.

DeMol P, Zissis G, Tubzler JP, et al. 1986. Failure of live attenuated oral rotavirus vaccine. Lancet, 2:108.

Dennehy PH, Brady RC, Halperin SA, et al. 2005. Comparative evaluation of safety and immunogenicity of two dosages of an oral live attenuated human rotavirus vaccine. Pediatr Infect Dis J, 24:481-8.

Dharakul T, Rott L, Greenberg HB. 1990. Recovery from chronic rotavirus infection in mice with severe combined immunodeficiency: virus clearance mediated by adoptive transfer of immune CD8+ T lymphocytes. $J$ Virol, 64:4375-82.

Dunn SJ, Ward RL, McNeal MM, et al. 1993. Identification of a new neutralization epitope on VP7 of human serotype 2 rotavirus and evidence for electropherotype differences caused by single nucleotide substitutions. Virology, 197:397-404.

Estes MK, Kapikain AZ. 2007. Rotaviruses. In Knipe DM, Howley PM ed. Fields Virology. Philadelphia:Lippincott, Williams and Wilkins, p 1917-74. 
Estes MK, Mason BB, Crawford S, et al. 1984. Cloning and nucleotide sequence of the simian rotavirus gene 6 that codes for the major inner capsid protein. Nucleic Acids Res, 12:1875-87.

Feng N, Burns JW, Bracy L, et al. 1994. Comparison of mucosal and systemic humoral immune responses and subsequent protection in mice orally inoculated with a homologous or a heterologous rotavirus. $J$ Virol, 68:7766-73.

Feng N, Lawton JA, Gilbert J, et al. 2002. Inhibition of rotavirus replication by a non-neutralizing, rotavirus VP6-specific IgA mAb. J Clin Invest, 109:1203-13.

Flewett TH, Bryden AS, Davies H, et al. 1974. Relation between viruses from acute gastroenteritis of children and newborn calves. Lancet, 2:61-3.

Flores J, Kapikian AZ. 1990. Vaccines against rotavirus. In Woodrow GC, Levine MM (ed). New Generation Vaccines. New York: Marcel Dekker, p 765-88.

Flores J, Perez-Schael I, Gonzalez M, et al. 1987. Protection against severe rotavirus diarrhoea by rhesus rotavirus vaccine in Venezuelan infants. Lancet, 1:882-4.

Franco MA, Greenberg HB. 1995. Role of B cells and cytotoxic T lymphocytes in clearance of and immunity to rotavirus infection in mice. J Virol, 69:7800-6.

Franco MA, Lefevre P, Willems P, et al. 1994. Identification of cytotoxic T cell epitopes on the VP3 and VP6 rotavirus proteins. J Gen Virol, 75:589-96.

Franco MA, Tin C, Greenberg HB. 1997. CD8 ${ }^{+}$T cells can mediate almost complete short-term and partial long-term immunity to rotavirus in mice. J Virol, 71:4165-70.

GAVI. 2001. GAVI task force for R\&D rotavirus vaccine agenda meeting WHO, Geneva.

Georges-Courbot MC, Monges J, Siopathis, MR, et al. 1991. Evaluation of the efficacy of a low-passage bovine rotavirus (strain WC3) vaccine in children in Central Africa. Res Virol, 142:405-11.

Glass RI, Lew JF, Gangarosa RE, et al. 1991. Estimates of morbidity and mortality rates for diarrheal diseases in American children. J Pediatr, 118:S27-33.

Glass RI, Parashar UD, Bresee JS, et al. 2006. Rotavirus vaccines: current prospects and future challenges. Lancet, 368:323-32.

Gorziglia M, Larralde G, Kapikian AZ, et al. 1990. Antigenic relationships among human rotaviruses as determined by outer capsid protein VP4. Proc Natl Acad Sci US A, 87:7155-9.

Hanlon P, Hanlon L, Marsh V, et al. 1987. Trial of an attenuated bovine rotavirus vaccine (RIT 4237) in Gambian infants. Lancet, $1: 1342-5$.

Hoshino Y, Wyatt RG, Greenberg HB, et al. 1984. Serotypic similarity and diversity of rotaviruses of mammalian and avian origin as studied by plaque-reduction neutralization. J Infect Dis, 149:694-702.

Institute of Medicine. 1986. Prospects for immunizing against rotavirus. New Vaccine Development: Establishing Priorities: Diseases of Importance in Developing Countries. Washington, D.C: National Academy Press, p 303-318.

Kapikian AZ, Cline WL, Kim HW, et al. 1976. Antigenic relationships among five reovirus-like (RVL) agents by complement fixation (CF) and development of new substitute CF antigens for the human RVL agent of infantile gastroenteritis. Proc Soc Exp Biol Med, 152:535-9.

Kapikian AZ, Flores J, Hoshino Y, et al. 1986. Rotavirus: the major etiologic agent of severe infantile diarrhea may be controllable by a "Jennerian" approach to vaccination. J Infect Dis, 153:815-22.

Lanata CF, Black RE, del Aguila R, et al. 1989. Protection of Peruvian children against rotavirus diarrhea of specific serotypes by one, two, or three doses of the RIT 4237 attenuated bovine rotavirus vaccine. J Infect Dis, 159:452-9.

Mackow ER, Shaw RD, Matsui SM, et al. 1988. The rhesus rotavirus gene encoding protein VP3: location of amino acids involved in homologous and heterologous rotavirus neutralization and identification of a putative fusion region. Proc Natl Acad Sci USA, 85:645-9.
Madore HP, Christy C, Pichichero M, et al. 1992. Field trial of rhesus rotavirus or human-rhesus rotavirus reassortant vaccine of VP7 serotype 3 or 1 specificity in infants. The Elmwood, Panorama, and Westfall Pediatric Groups. J Infect Dis, 166:235-43.

Malherbe H, Harwin R. 1963. The cytopathic effects of vervet monkey viruses. S Afr Med J, 37:407-11.

Matson DO, O'Ryan ML, Herrera I, et al. 1993. Fecal antibody responses to symptomatic and asymptomatic rotavirus infections. J Infect Dis, 167:577-83.

Matthews RE. 1979. The classification and nomenclature of viruses. Summary of results of meetings of the International Committee on Taxonomy of Viruses in The Hague, September 1978. Intervirology, 11:133-5.

McNeal MM, Barone KS, Rae MN, et al. 1995. Effector functions of antibody and CD8 + cells in resolution of rotavirus infection and protection against reinfection in mice. Virology, 214:387-97.

McNeal MM, Broome RL, Ward RL. 1994. Active immunity against rotavirus infection in mice is correlated with viral replication and titers of serum rotavirus IgA following vaccination. Virology, 204:642-50.

McNeal MM, Rae MN, Bean JA, et al. 1999. Antibody-dependent and -independent protection following intranasal immunization of mice with rotavirus particles. J Virol, 73:7565-73.

McNeal MM, Rae MN, Conner ME, et al. 1998. Stimulation of local immunity and protection in mice by intramuscular immunization with triple- or double-layered rotavirus particles and QS-21. Virology, 243:158-66.

McNeal MM, VanCott JL, Choi AH, et al. 2002. CD4 T cells are the only lymphocytes needed to protect mice against rotavirus shedding after intranasal immunization with a chimeric VP6 protein and the adjuvant LT(R192G). J Virol, 76:560-8.

Mebus CA, Underdahl NR, Rhodes MB, et al. 1969. Calf diarrhea (scours): Reproduced with a virus from a field outbreak. Univ Nebraska Res Bull, 233:1-16.

Morita Y, Taniguchi K, Urasawa T, et al. 1988. Analysis of serotypespecific neutralization epitopes on VP7 of human rotavirus by the use of neutralizing monoclonal antibodies and antigenic variants. J Gen Virol, 69:451-8.

Murphy BR, Morens DM, Simonsen L, et al. 2003. Reappraisal of the association of intussusception with the licensed live rotavirus vaccine challenges initial conclusions. J Infect Dis, 187:1301-8.

Nguyen TV, Yuan L, Azevedo MS, et al. 2006. High titers of circulating maternal antibodies suppress effector and memory B-cell responses induced by an attenuated rotavirus priming and rotavirus-like particleimmunostimulating complex boosting vaccine regimen. Clin Vaccine Immunol, 13:475-85.

O’Neal CM, Clements JD, Estes MK, et al. 1998. Rotavirus 2/6 viruslike particles administered intranasally with cholera toxin, Escherichia coli heat-labile toxin (LT), and LT-R192G induce protection from rotavirus challenge. J Virol, 72:3390-3.

O’Neal CM, Crawford SE, Estes MK, et al. 1997. Rotavirus virus-like particles administered mucosally induce protective immunity. $J$ Virol, 71:8707-17

O’Ryan ML, Matson DO, Estes MK, et al. 1994. Anti-rotavirus G type-specific and isotype-specific antibodies in children with natural rotavirus infections. J Infect Dis, 169:504-11.

Offit PA, Boyle DB, Both GW, et al. 1991. Outer capsid glycoprotein vp7 is recognized by cross-reactive, rotavirus-specific, cytotoxic T lymphocytes. Virology, 184:563-8.

Offit PA, Dudzik KI. 1988. Rotavirus-specific cytotoxic T lymphocytes cross-react with target cells infected with different rotavirus serotypes. J Virol, 62:127-31

Offit PA, Dudzik KI. 1990. Rotavirus-specific cytotoxic T lymphocytes passively protect against gastroenteritis in suckling mice. $J$ Virol, 64:6325-8.

Padilla-Noriega L, Fiore L, Rennels MB, et al. 1992. Humoral immune responses to VP4 and its cleavage products VP5* and VP8* in infants vaccinated with rhesus rotavirus. J Clin Microbiol, 30:1392-7. 
Pappenheimer AW, Enders JF. 1947. An epidemic diarrheal disease of suckling mice. II Inclusions in the intestional epithelial cells. $J$ Exp Med, 85:417-422.

Parashar UD, Gibson CJ, Bresse JS, et al. 2006. Rotavirus and severe childhood diarrhea. Emerg Infect Dis, 12:304-6.

Parez N, Fourgeux C, Mohamed A, et al. 2006. Rectal immunization with rotavirus virus-like particles induces systemic and mucosal humoral immune responses and protects mice against rotavirus infection. J Virol, 80:1752-61.

Phua KB, Quak SH, Lee BW, et al. 2005. Evaluation of RIX4414, a live, attenuated rotavirus vaccine, in a randomized, double-blind, placebocontrolled phase 2 trial involving 2464 Singaporean infants. $J$ Infect Dis, 192:S6-S16.

Prasad BV, Chiu W. 1994. Structure of rotavirus. Curr Top Microbiol Immunol, 185:9-29.

Ready KFM, Sabara M. 1987. In vitro assembly of bovine rotavirus nucleocapsid protein. Virology, 157:189-98.

Research priorities for diarroeal diseases vaccines. 1991. Bull World Health Organ, 69:667-676.

Ruiz-Palacios GM, Perez-Schael I, Velazquez FR, et al. 2006. Safety and efficacy of an attenuated vaccine against severe rotavirus gastroenteritis. N Engl J Med, 354:11-22.

Saif LJ, Bohl EH, Theil KW, et al. 1980. Rotavirus-like, calicivirus-like, and 23-nm virus-like particles associated with diarrhea in young pigs. J Clin Microbiol, 12:105-11.

Saif LJ, Jiang B. 1994. Nongroup A rotaviruses of humans and animals. Curr Top Microbiol Immunol, 185:339-71.

Santosham M, Letson GW, Wolff M, et al. 1991. A field study of the safety and efficacy of two candidate rotavirus vaccines in a Native American population. J Infect Dis, 163:483-7.

Schwartz-Cornil I, Benureau Y, Greenberg H, Hendrickson B A, Cohen J. (2002). Heterologous protection induced by the inner capsid proteins of rotavirus requires transcytosis of mucosal immunoglobulins. $J$ Virol, 76(16):8110-7.

Shaw AL, Rothnagel R, Chen D, et al. 1993. Three-dimensional visualization of the rotavirus hemagglutinin structure. Cell, 74:693-701.

Smiley KL, McNeal MM, Basu M, et al. 2007. Association of IFN $\gamma$ and IL-17 production in intestinal $\mathrm{CD}^{+} \mathrm{T}$ cells with protection against rotavirus shedding in mice intranasally immunized with VP6 and the adjuvant LT(R192G). $J$ Virol, 81:3740-8.

Snodgrass DR, Hoshino Y, Fitzgerald TA, et al. 1992. Identification of four VP4 serological types (P serotypes) of bovine rotavirus using viral reassortants. J Gen Virol, 73:2319-25.

Taniguchi K, Maloy WL, Nishikawa K, et al. 1988. Identification of crossreactive and serotype 2-specific neutralization epitopes on VP3 of human rotavirus. $J$ Virol, 62:2421-6.

To TL, Ward LA, Yuan L, et al. 1998. Serum and intestinal isotype antibody responses and correlates of protective immunity to human rotavirus in a gnotobiotic pig model of disease. J Gen Virol, 79:2661-72.

Treanor JJ, Clark HF, Pichichero M, et al. 1995. Evaluation of the protective efficacy of a serotype 1 bovine-human rotavirus reassortant vaccine in infants. Pediatr Infect Dis J, 14:301-7.

VanCott JL, Prada AE, McNeal MM, et al. 2006. Mice develop effective but delayed protective immune responses when immunized as neonates either intranasally with nonliving VP6/LT(R192G) or orally with live rhesus rotavirus vaccine candidates. $J$ Virol, 80:4949-61.

Velazquez FR, Matson DO, Calva JJ, et al. 1996. Rotavirus infections in infants as protection against subsequent infections. $N$ Engl $J$ Med, 335:1022-8.

Velazquez FR, Matson DO, Guerrero ML, et al. 2000. Serum antibody as a marker of protection against natural rotavirus infection and disease. J Infect Dis, 182:1602-9.
Vesikari T, Isolauri E, Delem A, et al. 1985. Clinical efficacy of the RIT 4237 live attenuated bovine rotavirus vaccine in infants vaccinated before a rotavirus epidemic. J Pediatr, 107:189-94.

Vesikari T, Isolauri E, Delem A, et al. 1983. Immunogenicity and safety of live oral attenuated bovine rotavirus vaccine strain RIT 4237 in adults and young children. Lancet, 2:807-11.

Vesikari T, Karvonen A, Korhonen T, et al. 2004. Safety and immunogenicity of RIX4414 live attenuated human rotavirus vaccine in adults, toddlers and previously uninfected infants. Vaccine, 22:2836-42.

Vesikari T, Karvonen A, Korhonen T, et al. 2006. Abstract of 24th Annual Meeting of the European Society for Pediatric Infectious Diseases, Basel, Switzerland.

Vesikari T, Karvonen A, Puustinen L, et al. 2004. Efficacy of RIX4414 live attenuated human rotavirus vaccine in Finnish infants. Pediatr Infect Dis J, 23:937-43.

Vesikari T, Karvonen AV, Majuri J, et al. 2006. Safety, efficacy, and immunogenicity of 2 doses of bovine-human (UK) and rhesus-rhesushuman rotavirus reassortant tetravalent vaccines in Finnish children. J Infect Dis, 194:370-6.

Vesikari T, Matson DO, Dennehy P, et al. 2006. Safety and efficacy of a pentavalent human-bovine (WC3) reassortant rotavirus vaccine. $N$ Engl J Med, 354:23-33.

Vesikari T, Rautanen T, Varis T, et al. 1990. Rhesus Rotavirus candidate vaccine. Clinical trial in children vaccinated between 2 and 5 months of age. Am J Dis Child, 144:285-9.

Ward RL, Bernstein DI, Shukla R, et al. 1989. Effects of antibody to rotavirus on protection of adults challenged with a human rotavirus. J Infect Dis, 159:79-88.

Ward RL, Knowlton DR, Schiff GM, et al. 1988. Relative concentrations of serum neutralizing antibody to VP3 and VP7 proteins in adults infected with a human rotavirus. $J$ Virol, 62:1543-9.

Ward RL, McNeal MM, Sander DS, et al. 1993. Immunodominance of the VP4 neutralization protein of rotavirus in protective natural infections of young children. $J$ Virol, 67:464-8.

Ward RL, McNeal MM, Sheridan JF. 1992. Evidence that active protection following oral immunization of mice with live rotavirus is not dependent on neutralizing antibody. Virology, 188:57-66.

Woode GN, Zheng S, Rosen BI, et al. 1987. Protection between different serotypes of bovine rotavirus in gnotobiotic calves: specificity of serum antibody and coproantibody responses. J Clin Microbiol, 25:1052-8.

Wyatt RG, Greenberg HB, James WD, et al. 1982. Definition of human rotavirus serotypes by plaque reduction assay. Infect Immun, 37:110-5.

Wyatt RG, Kalica AR, Mebus CA, et al. 1978. Reovirus-like agents (rotaviruses) associated with diarrheal illness in animals and man In M. Pollard ed. Perspectives in Virology. New York: Raven Press, p 121-145.

Yeager M, Berriman JA, Baker TS, Bellamy AR. 1994. Three-dimensional structure of the rotavirus haemagglutinin VP4 by cryo-electron microscopy and difference map analysis. Embo J, 13:1011-8.

Yoder JD, Dormitzer PR. 2006. Alternative intermolecular contacts underlie the rotavirus VP5* two- to three-fold rearrangement. Embo $J, 25: 1559-68$

Yuan L, Geyer A, Hodgins DC, et al. 2000. Intranasal administration of 2/6-rotavirus-like particles with mutant Escherichia coli heat-labile toxin (LT-R192G) induces antibody-secreting cell responses but not protective immunity in gnotobiotic pigs. $J$ Virol, 74:8843-53.

Yuan L, Saif LJ. 2002. Induction of mucosal immune responses and protection against enteric viruses: rotavirus infection of gnotobiotic pigs as a model. Vet Immunol Immunopathol, 87:147-60. 
